\title{
ALLERGIC DISEASES AND ATOPY AMONG SCHOOLCHILDREN IN EASTERN CROATIA
}

\author{
Neda Aberle ${ }^{1}$, Blaženka Kljaić Bukvić ${ }^{2}$ Mario Blekić ${ }^{2}$, Marko Vučković2, \\ Darija Bardak ${ }^{3}$, Antoneta Gudelj ${ }^{4}$, Gabrijela Čančarević ${ }^{5}$ and Maja Franićc
}

${ }^{1}$ Department of Health Studies, University of Zadar, Zadar, Croatia; ${ }^{2}$ Department of Pediatrics, Dr Josip Benčević General Hospital, Slavonski Brod, Croatia; School of Medicine, Josip Juraj Strossmayer University of Osijek, Osijek, Croatia; ${ }^{3}$ Department of Internal Diseases, Požega General Hospital, Požega, Croatia;

${ }^{4}$ ENT, Head and Neck Surgery Department, Dr Josip Benčević General Hospital, Slavonski Brod, Croatia;

${ }^{5}$ Department of Pediatrics, Nova Gradiška General Hospital, Nova Gradiška, Croatia;

${ }^{6}$ Department of Internal Diseases, Dr Josip Benčević General Hospital, Slavonski Brod, Croatia

SUMMARY - A cross-sectional study was carried out in Brod-Posavina County, Croatia, to assess the prevalence of allergic diseases and atopy, as well as to investigate the possible etiologic factors for asthma, allergic rhinitis and eczema in childhood. The study included 1687 schoolchildren aged 10-11 years. Data were collected using standardized International Study of Asthma and Allergies in Childhood (ISAAC) Phase II written questionnaire. Skin prick tests were performed to provide an objective measure of atopy, defined as skin reactivity to one or more allergens. Lifetime prevalence of wheezing was $22.7 \%$, rhinitis symptoms $22.5 \%$, and eczema symptoms $17.9 \%$. Period prevalence in the past 12 months was $7.9 \%$ for attacks of wheezing, $9.9 \%$ for rhinoconjunctivitis symptoms, and $10.1 \%$ for eczema symptoms. Of the children in which skin prick test was performed, $20.2 \%$ were positive for at least one of the allergens used, with house dust mite sensitization being the most frequent one. Risk factors for allergic disease include allergic disease in family, atopy, sensitization to indoor and outdoor allergens, and environmental tobacco smoke exposure at home. International comparison with the results of other ISAAC Phase II studies showed the Brod-Posavina County to be an area with moderate prevalence of atopy and current asthma symptoms.

Key words: Hypersensitivity; Prevalence; Risk factors; Asthma; Rhinitis, allergic; Dermatitis, atopic; Cross-sectional studies; Child; Croatia

\section{Introduction}

Allergic diseases with complex etiology, such as asthma, allergic rhinitis and eczema, are the most common chronic conditions in childhood. The prevalence of these allergic diseases has constantly and significantly increased worldwide in recent decades ${ }^{1}$. Over the last several years, countries in transition have experienced a dramatic increase in allergic diseases ${ }^{2}$. However, publi-

Correspondence to: Blaženka Kljaić Bukvić, MD, PhD, Department of Pediatrics, Dr Josip Benčević General Hospital, Ulica Andrije Štampara 42, HR-35000 Slavonski Brod, Croatia E-mail: bkbukvic@gmail.com

Received June 26, 2017, accepted December 21, 2017 cations from high-income countries at the end of the $20^{\text {th }}$ century reported a moderate decrease in asthma and atopic diseases in older age groups of children ${ }^{3-6}$. Moreover, according to data from the International Study of Asthma and Allergies in Childhood (ISAAC) Phase III, previous observations that asthma is more prevalent in affluent than in non-affluent countries ${ }^{7}$ cannot be considered accurate. This epidemiologic survey has documented great variability in asthma and allergic disease prevalence not just among different countries, but also among centers in the same country. The cause of the recorded increase and differences in the prevalence is complex. It has been assumed that changes in local environmental exposures, combined with ge- 
netic susceptibility could account for the observed variability. The observed environmental risk factors for allergic diseases include indoor and outdoor environment, diet, lifestyle, stress, use of antibiotics, and family size. Complete development of allergic phenotype is influenced by the period in which it has occurred (early childhood - prenatal and early postnatal). However, epidemiologic data indicate differences in risk factors for asthma among countries ${ }^{8}$.

Although researchers in Croatia (a country that is part of both Mediterranean and Central Europe) have previously written about asthma, rhinitis and eczema in various parts of Croatia ${ }^{9-16}$, there was little data about atopy, environmental exposures and lifestyle that could be associated with asthma in the Croatian population. Considering the great variability of published data in terms of prevalence of allergic diseases among different centers in Croatia and scarce data published on predisposing exposures, the aim of our study was to assess the prevalence of asthma, allergic rhinitis, eczema and atopy in childhood in Brod-Posavina County (eastern Croatia), as well as the risk factors for these allergic diseases.

\section{Materials and Methods}

\section{Study design and setting}

This cross-sectional study was carried out in BrodPosavina County, which is part of Slavonia, one of the four historical regions of Croatia. It is located in the Pannonian Basin, which is bordered by the Danube, Drava and Sava rivers. The western part of the region consists of the Sava and Drava valleys, and the mountains and hills surrounding the Požega valley, the highest being Psunj with $984 \mathrm{~m}$ above sea level. The eastern part of the region consists of plains. Slavonia enjoys a moderately warm and rainy continental climate, with relatively low precipitation.

Parental consent was obtained before the study. The study was approved by the ethics committees of the participating institutions.

\section{Participants}

Between September 2007 and June 2008, children aged 10-11 from all elementary schools in the BrodPosavina County ( $\mathrm{N}=2224)$ were asked to participate in the study, which included a questionnaire for parents and skin prick test (SPT).

\section{Methods}

Data were collected using the standardized ISAAC Phase II written questionnaire ${ }^{17-19}$. The core questionnaire includes demographic characteristics: gender of the child, parental age and education, family history of atopy, and questionnaires on wheezing, rhinitis and eczema.

Supplementary questionnaires include the risk factor questionnaire, inquiring about early days: birth weight, breastfeeding, attendance of nursery or kindergarten, and number of older siblings. The second part of the questionnaire refers to characteristics of the child's home during conducting the survey and during the first year of life: pet ownership, contact with farm animals, cooking/heating fuel, surroundings and environmental tobacco smoke exposure ${ }^{19}$.

Skin prick test was performed to provide an objective measure of atopy, defined as skin reactivity to one or more allergens. Sensitization to the following eight allergens was assessed: Dermatophagoides (D.) pteronyssinus, dog, cat, egg, peanut, ragweed, birch and mixed grass pollen. Standardized allergen extracts and control solution were obtained from Stallergens (France). A wheal size $\geq 3 \mathrm{~mm}$ after subtraction of negative control was considered positive. The presence of visible flexural dermatitis was determined by skin examination.

\section{Statistical analysis}

Statistical analysis was carried out using SPSS 19 (SPSS Inc., Chicago, IN, USA). Symptom prevalence was calculated by dividing the number of positive responses to each question by the number of completed questionnaires. We analyzed associations between environmental exposures and main research outcomes (current wheezing, current rhinoconjunctivitis and current eczema) using logistic regression. Results were presented as $\mathrm{p}$ values, odds ratios (OR) and 95\% confidence intervals $(95 \% \mathrm{CI})$ as a measure of effect size.

\section{Results}

Of 2224 children that were approached, 1687 agreed to participate in the study (response rate $75 \% ; 847$ (50.2\%) male and 840 (49.9\%) female). Description of the study population is shown in Table 1 . We observed that $67.7 \%$ of children had mothers under the age of 40 , and $56 \%$ of them had fathers above the age of 40 . Par- 
ents had elementary or high school education (only $9.4 \%$ of children had mothers and $11.6 \%$ had fathers with university education). Positive family history of atopy was recorded in one-fifth of the participants. Two-thirds of study children were raised in small families (one child or two children). One-fifth of the study families had pets (a cat or dog), but only 14\% of them had pets (a cat or dog) while their children were infants. Current contact with farm animals was reported for $16.9 \%$ of children, while $9.6 \%$ of children were in contact with farm animals in infancy. Families mostly used gas for cooking and wood for heating. According to residence, $59.5 \%$ of children lived in rural areas and $40.5 \%$ in urban areas (Table 2). At home, $54.1 \%$ of children were currently exposed to environmental tobacco smoke by any household member (Table 3 ).

\section{Prevalence}

The prevalence of allergic disorders is shown in Table 4. According to written questionnaire, wheezing during childhood was present in 383 (22.7\%) children. Wheezing during previous 12 months was reported by 134 (7.9\%) children, with significantly more wheezing in boys than girls ( $59.7 \%$ vs. $40.3 \%, \mathrm{p}=0.02)$. The prevalence of diagnosed asthma was $4.1 \%$, with significantly more boys than girls suffering from asthma (boys $63.2 \%$ vs. girls $36.8 \%$, $\mathrm{p}=0.03$ ).

The lifetime prevalence of rhinitis symptoms was $22.5 \%$, while $325(19.3 \%)$ children reported having the same nasal problems during the past 12 months. In 167 (9.9\%) cases, nasal symptoms were associated with conjunctivitis. There was no gender difference in nasal symptoms. Itchy rash was reported by 301 (17.9\%) children, with a lower prevalence of eczema symptoms during the previous 12 months (10.1\%). Visible flexural dermatitis was recorded in $1.9 \%$ of study children.

The SPT participation rate was $48.1 \%$ (1070/2224). The prevalence of atopy was $20.2 \%$ (216 children had positive skin prick test for at least one of the allergens used), with house dust mite sensitization being the most frequent one $(146 / 1070,13.6 \%)$. The prevalence of atopic wheeze (defined as current wheeze plus SPT reactivity) was $3 \%$.

\section{Risk factors for current wheezing}

The risk factors for current wheezing were male gender, environmental tobacco smoke exposure now and during early life, family history of atopy, atopy,
Table 1. Characteristics of study population

\begin{tabular}{|l|l|l|}
\hline Characteristic & $\mathrm{N}^{*}$ & $\mathrm{n}(\%)$ \\
\hline $\begin{array}{l}\text { Maternal age } \\
>40\end{array}$ & 1687 & $\begin{array}{l}1152(67.7) \\
535(31.4)\end{array}$ \\
\hline $\begin{array}{l}\text { Paternal age } \\
<40 \\
>40\end{array}$ & 1687 & $734(43.1)$ \\
\hline $\begin{array}{l}\text { Maternal education } \\
0-12 \text { years } \\
\geq 13 \text { years }\end{array}$ & 1654 & $1494(87.8)$ \\
\hline $\begin{array}{l}\text { Paternal education } \\
0-12 \text { years } \\
\geq 13 \text { years }\end{array}$ & 1635 & $160(9.4)$ \\
\hline Family history of atopy & 943 & $1435(84.3)$ \\
\hline $\begin{array}{l}\text { Birth weight } \\
<1999 \text { g } \\
2000-2499 \text { g } \\
>2500 \text { g }\end{array}$ & 1651 & $363(21.3)$ \\
\hline Breastfeeding - yes & & $\begin{array}{l}51(3.0) \\
96(5.6)\end{array}$ \\
\hline Nursery & 1687 & $1504(88.4)$ \\
\hline Kindergarten & 1662 & $225(13.2)$ \\
\hline $\begin{array}{l}\text { Older siblings } \\
0\end{array}$ & 1663 & $499(29.2)$ \\
\hline $\begin{array}{l}1 \\
\geq 2\end{array}$ & 1687 & $565(33.2)$ \\
\hline
\end{tabular}

$\mathrm{n}^{*}=$ number of participants with valid answer

SPT positive for $D$. pteronyssinus, grass and ragweed (Table 5). Symptoms of rhinoconjunctivitis and eczema were risk factors for wheezing over the last 12 months. Parental education, place of birth and place of residence, events in perinatal and infant periods (weight at birth, term of birth, breastfeeding, attending a child care or kindergarten), home environment and surrounding area (urban/rural, contact with furry pets and farm animals, damp spots, moulds or fungus on the walls, and fuel used for cooking and heating) were not associated with asthma.

\section{Risk factors for current rhinoconjunctivitis}

We observed significant association between current rhinoconjunctivitis and family history of allergic disorders and atopy. Positive SPT for D. pteronyssinus, ragweed and birch increased, while the influence of ru- 
Table 2. Characteristics of child household during conducting the questionnaire and during the $1^{\text {st }}$ year of life

\begin{tabular}{|c|c|c|c|c|}
\hline Characteristic & $\mathrm{N}^{*}$ & $\begin{array}{l}\text { During conducting } \\
\text { the questionnaire }\end{array}$ & $\mathrm{N}^{*}$ & $\begin{array}{l}\text { During } 1^{\text {st }} \text { year } \\
\text { of life }\end{array}$ \\
\hline Cat in home & 1611 & $360(21.2 \%)$ & 1617 & $248(14.6 \%)$ \\
\hline Dog in home & 1619 & $374(22.0 \%)$ & 1626 & $245(14.4 \%)$ \\
\hline $\begin{array}{l}\text { Contact with } \\
\text { farm animals }\end{array}$ & 1626 & $287(16.9 \%)$ & 1620 & $164(9.6 \%)$ \\
\hline \multicolumn{5}{|l|}{ Cooking fuel } \\
\hline Electricity & 1650 & $642(37.7 \%)$ & 1636 & $627(36.8 \%)$ \\
\hline Gas & 1644 & $1404(82.5 \%)$ & 1638 & 1207 (70.9\%) \\
\hline Wood or coal & 1646 & $561(33.0 \%)$ & 1636 & 699 (41.1\%) \\
\hline \multicolumn{5}{|l|}{ Heating fuel } \\
\hline Electricity & 1634 & $150(8.8 \%)$ & 1629 & $177(10.4 \%)$ \\
\hline Gas & 1633 & $554(32.6 \%)$ & 1626 & $285(16.8 \%)$ \\
\hline Wood & 1651 & $1114(65.5 \%)$ & 1638 & $1222(71.8 \%)$ \\
\hline Coal & 1634 & $21(1.2 \%)$ & 1624 & $28(1.7 \%)$ \\
\hline Oil & 1622 & $56(3.3 \%)$ & 1611 & $122(7.2 \%)$ \\
\hline Surrounding area & 1675 & & 1675 & \\
\hline Rural & & $996(59.5 \%)$ & & 991 (58.7\%) \\
\hline Urban & & $679(40.5 \%)$ & & $677(40.1 \%)$ \\
\hline
\end{tabular}

*n $_{n}$ number of participants with valid answer

Table 3. Environmental tobacco smoke exposure by mother and any household member through three stages of child life (during conducting the questionnaire, $1^{\text {st }}$ year of life and pregnancy)

\begin{tabular}{|l|l|l|l|l|l|l|}
\hline & $\mathrm{N}^{*}$ & $\begin{array}{l}\text { During conducting } \\
\text { the questionnaire }\end{array}$ & $\mathrm{N}^{*}$ & $\begin{array}{l}\text { During 1 1tyear } \\
\text { of life }\end{array}$ & $\mathrm{N}^{*}$ & $\begin{array}{l}\text { During } \\
\text { pregnancy }\end{array}$ \\
\hline $\begin{array}{l}\text { Mother } \\
\text { Any household member } \\
\begin{array}{l}\text { Number of cigarettes } \\
<10\end{array}\end{array}$ & 1663 & $613(36.0 \%)$ & 1656 & $523(30.7 \%)$ & 1646 & $328(19.3 \%)$ \\
$10-20$ & $921(54.1 \%)$ & & & & \\
$>20$ & 929 & $374(22.0 \%)$ & & & & \\
& 929 & $406(23.9 \%)$ & & & & \\
\hline
\end{tabular}

${ }^{*} \mathrm{n}=$ number of participants with valid answer

ral setting in the $1^{\text {st }}$ year of life reduced the risk of current rhinoconjunctivitis. Wheezing and eczema were strongly associated with current nasal and eye symptoms (Table 6).

\section{Risk factors for current eczema}

Current eczema was significantly higher among girls compared to boys. Family history of atopy increased the risk of eczema, which was even greater if the mother also suffered from an allergic disease. We observed significant associations of current eczema with positive SPT for $D$. pteronyssinus, wheezing and rhinitis (Table 6).

\section{Discussion}

The results of our study (within the context of ISAAC Phase II) contribute to previously published 
Table 4. Prevalence of wheezing, rhinitis, rhinoconjunctivitis and eczema

\begin{tabular}{|c|c|c|c|}
\hline $\begin{array}{l}\text { Symptoms of } \\
\text { allergic disease }\end{array}$ & $\begin{array}{l}\text { Sample } \\
(\mathrm{N})\end{array}$ & $\begin{array}{l}\text { Positive } \\
\text { answer (n) }\end{array}$ & Prevalence \\
\hline Wheezing ever & 1684 & 383 & $22.7 \%$ \\
\hline $\begin{array}{l}\text { Wheezing in the last } \\
12 \text { months }\end{array}$ & 1684 & 134 & $7.9 \%$ \\
\hline Dg asthma & 1672 & 68 & $4.1 \%$ \\
\hline Rhinitis ever & 1683 & 379 & $22.5 \%$ \\
\hline $\begin{array}{l}\text { Rhinitis in the last } \\
12 \text { months }\end{array}$ & 1687 & 325 & $19.3 \%$ \\
\hline $\begin{array}{l}\text { Rhinoconjunctivitis } \\
\text { in the last } 12 \text { months }\end{array}$ & 1683 & 167 & $9.9 \%$ \\
\hline Dg pollinosis & 1678 & 106 & $6.3 \%$ \\
\hline Eczema ever & 1680 & 301 & $17.9 \%$ \\
\hline $\begin{array}{l}\text { Eczema in the last } \\
12 \text { months }\end{array}$ & 1680 & 170 & $10.1 \%$ \\
\hline Dg eczema & 1676 & 198 & $11.8 \%$ \\
\hline
\end{tabular}

Table 5. Prevalence of atopic sensitization

\begin{tabular}{|l|l|l|l|}
\hline & Sample (N) & Positive SPT (n) & $\%$ \\
\hline Atopy & 1070 & 216 & 20.2 \\
D. pteronyssinus & 1070 & 146 & 13.6 \\
Cat & 1070 & 17 & 1.6 \\
Dog & 1070 & 28 & 2.6 \\
Birch & 1070 & 24 & 2.2 \\
Ragweed & 1070 & 78 & 7.3 \\
Grass & 1070 & 52 & 4.9 \\
Egg & 1070 & 19 & 1.8 \\
Peanut & 1070 & 17 & 1.6 \\
\hline
\end{tabular}

$\mathrm{SPT}=$ skin prick test $D$. pteronyssinus $=$ Dermatophagoides pteronyssinus

data on the prevalence of asthma and allergic disease in childhood. Lifetime prevalence of wheezing, rhinitis symptoms and eczema symptoms was $22.7 \%, 22.5 \%$ and $17.8 \%$, respectively. Period prevalence in the last 12 months was $7.9 \%$ for attacks of wheezing or whistling in the chest, $19.3 \%$ for rhinitis, $9.9 \%$ for rhinoconjunctivitis symptoms, and $10.0 \%$ for eczema symptoms. In addition, we assessed the prevalence of atopic sensitization and risk factors for the symptoms of allergic disease for the first time in Croatian schoolchildren. Among SPT tested children, 216 (20.2\%) had positive reaction to at least one of the allergens used, with house dust mite sensitization being the most fre- quent one. The percentage of SPT results for each allergen was as follows: $D$. pteronyssinus $13.6 \%$, ragweed $7.3 \%$, grass $4.9 \%$, dog $2.6 \%$, birch $2.2 \%$, egg $1.8 \%$, cat $1.6 \%$, and peanut $1.6 \%$. The strongest risk factors for current wheezing were specific sensitization to $D$. pteronyssinus and current eczema. Also, positive SPT to ragweed increased the risk of asthma. Sensitization to grass and atopy contributed to fourfold increase in the risk of current wheezing. Environmental tobacco smoke, especially during infancy, family history of atopy, rhinitis, current rhinoconjunctivitis, and male gender were independent risk factors for wheezing in the past 12 months.

Positive SPT for pollen (ragweed and birch) was the strongest risk factor for current rhinoconjunctivitis. Also, family history of allergic disorders, atopy, positive SPT for D. pteronyssinus, wheezing (current and ever) and eczema increased the risk, while rural setting in infancy reduced the risk of current nasal and eye symptoms.

The strongest risk factors for current eczema included allergic diseases, rhinitis and wheezing. We also found an increased risk in girls, and in children with family history of atopy and specific sensitization to $D$. pteronyssinus.

The design of our study was cross sectional. We used the methodology of ISAAC Phase II using a standardized written questionnaire of self-reported symptoms. The recommended sample size was 3000 to ensure good prevalence estimates for severe asthma, but centers like the one in Brod-Posavina County with a small number of inhabitants were also included in ISAAC. We did not use video questionnaire. Data on environmental exposures such as environmental tobacco smoke exposure were assessed by a questionnaire rather than by objective measurement (e.g., cotinine) and collected retrospectively, which may affect real exposure. Also, environmental exposures may be influenced by behavior and affection status of parents towards the children included.

The prevalence of asthma and allergic disease dramatically increased in the second half of the $20^{\text {th }}$ century. Data showing the increase in asthma prevalence among Croatian children were collected in a similar manner as data from the whole world in the same period (using surveys with non-standardized methodologies $)^{11}$. Over the last two decades, several standardized epidemiologic surveys (using ISAAC Phase I 
Table 6. Risk factors for allergic disease: wheezing during the last 12 months (i.e. current wheezing), rbinoconjunctivitis during the last 12 months (i.e. current rhinoconjunctivitis), and eczema during the last 12 months (i.e. current eczema)

\begin{tabular}{|c|c|c|c|c|c|c|c|c|c|c|}
\hline \multirow{2}{*}{\multicolumn{2}{|c|}{ Risk factor }} & \multicolumn{3}{|c|}{ Current wheezing } & \multicolumn{3}{|c|}{ Current rhinoconjunctivitis } & \multicolumn{3}{|c|}{ Current eczema } \\
\hline & & OR & $95 \% \mathrm{CI}$ & $\mathrm{p}$ & OR & $95 \% \mathrm{CI}$ & $\mathrm{p}$ & OR & $95 \% \mathrm{CI}$ & $\mathrm{p}$ \\
\hline \multicolumn{2}{|l|}{ Male } & 1.51 & $1.06-2.15$ & 0.03 & NS & NS & NS & NS & NS & NS \\
\hline \multicolumn{2}{|l|}{ Female } & NS & NS & NS & NS & NS & NS & 1.39 & $1.01-1.91$ & 0.02 \\
\hline \multicolumn{2}{|c|}{$\begin{array}{l}\text { Mother smoking } \\
\text { current } \\
1^{\text {st }} \text { year }\end{array}$} & $\begin{array}{l}1.65 \\
2.2\end{array}$ & $\begin{array}{l}1.43-2.4 \\
1.5-3.23\end{array}$ & $\begin{array}{l}0.01 \\
0.00\end{array}$ & $\begin{array}{l}\text { NS } \\
\text { NS }\end{array}$ & $\begin{array}{l}\text { NS } \\
\text { NS }\end{array}$ & $\begin{array}{l}\text { NS } \\
\text { NS }\end{array}$ & $\begin{array}{l}\text { NS } \\
\text { NS }\end{array}$ & $\begin{array}{l}\text { NS } \\
\text { NS }\end{array}$ & $\begin{array}{l}\text { NS } \\
\text { NS }\end{array}$ \\
\hline \multicolumn{2}{|c|}{$\begin{array}{l}\text { Family history } \\
\text { of allergic disease }\end{array}$} & 2.26 & $1.42-3.6$ & 0.00 & 2.87 & $1.76-4.67$ & 0.00 & 2.32 & $1.56-3.45$ & 0.00 \\
\hline \multicolumn{2}{|c|}{ Rural setting, $1^{\text {st }}$ year } & NS & NS & NS & 0.61 & 0.4-0.93 & 0.02 & NS & NS & NS \\
\hline \multicolumn{2}{|l|}{ Atopy } & 4.03 & $2.27-7.15$ & 0.00 & 2.15 & $1.28-3.6$ & 0.00 & NS & NS & NS \\
\hline \multicolumn{2}{|c|}{ SPT D. pteronyssinus } & 7.65 & $3.91-14.97$ & 0.00 & 1.99 & $1.12-3.54$ & 0.02 & 1.82 & $1.07-3.1$ & 0.03 \\
\hline \multicolumn{2}{|l|}{ SPT grass } & 4.74 & $1.62-13.85$ & 0.01 & 3.32 & $1.09-10.15$ & 0.03 & NS & NS & NS \\
\hline \multicolumn{2}{|c|}{ SPT ragweed } & 5.47 & $2.26-13.27$ & 0.00 & 3.03 & $1.59-5.78$ & 0.00 & NS & NS & NS \\
\hline Wheezing & \begin{tabular}{|l} 
ever \\
current
\end{tabular} & $\begin{array}{l}\text { NA } \\
\text { NA }\end{array}$ & $\begin{array}{l}\text { NA } \\
\text { NA }\end{array}$ & $\begin{array}{l}\text { NA } \\
\text { NA }\end{array}$ & $\begin{array}{l}2.95 \\
2.54\end{array}$ & \begin{tabular}{|l|}
$1.96-4.44$ \\
$1.45-4.47$
\end{tabular} & $\begin{array}{l}0.00 \\
0.00\end{array}$ & $\begin{array}{l}3.93 \\
4.17\end{array}$ & \begin{tabular}{|l}
$2.69-5.74$ \\
$2.24-7.78$
\end{tabular} & $\begin{array}{l}0.00 \\
0.00\end{array}$ \\
\hline Rhinitis & \begin{tabular}{|l} 
ever \\
current
\end{tabular} & $\begin{array}{l}17.67 \\
15.97\end{array}$ & $\begin{array}{l}11.34-27.55 \\
10.21-24.97\end{array}$ & $\begin{array}{l}0.00 \\
0.00\end{array}$ & $\begin{array}{l}\text { NA } \\
\text { NA }\end{array}$ & $\begin{array}{l}\text { NA } \\
\text { NA }\end{array}$ & $\begin{array}{l}\mathrm{NA} \\
\mathrm{NA}\end{array}$ & $\begin{array}{l}6.95 \\
9.38\end{array}$ & $\begin{array}{l}4.75-10.15 \\
6.27-14.01\end{array}$ & $\begin{array}{l}0.00 \\
0.00\end{array}$ \\
\hline Eczema & $\begin{array}{l}\text { ever } \\
\text { current }\end{array}$ & $\begin{array}{l}5.52 \\
7.47\end{array}$ & \begin{tabular}{|l|}
$3.48-8.74$ \\
$4.16-13.43$ \\
\end{tabular} & $\begin{array}{l}0.00 \\
0.00\end{array}$ & $\begin{array}{l}1.89 \\
2.67\end{array}$ & \begin{tabular}{|l|}
$1.24-2.88$ \\
$1.48-4.79$
\end{tabular} & $\begin{array}{l}0.00 \\
0.00\end{array}$ & $\begin{array}{l}\mathrm{NA} \\
\mathrm{NA}\end{array}$ & $\begin{array}{l}\text { NA } \\
\text { NA }\end{array}$ & $\begin{array}{l}\mathrm{NA} \\
\mathrm{NA}\end{array}$ \\
\hline
\end{tabular}

$\mathrm{OR}=$ odds ratio $; 95 \% \mathrm{CI}=95 \%$ confidence interval; $\mathrm{p}<0.05 ; \mathrm{SPT}=$ skin prick test D. pteronyssinus $=$ Dermatophagoides pteronyssinus ; $\mathrm{NS}$ = nonsignificant; $\mathrm{NA}=$ not available

written and video questionnaire and Phase II written questionnaire) were conducted in different Croatian counties $^{11-13,15}$. They included different age groups of children: 6-7 years, 10-11 years, $12-14$ and 14-16 years. In comparison to the research conducted in $\mathrm{Za}-$ greb $^{15}$, Primorje-Gorski Kotar County ${ }^{11}$ and Medimurje County ${ }^{13}$, we recorded a higher prevalence of current wheezing (Brod-Posavina County 7.9\%) as compared with Zagreb (6.02\%) and Medimurje County (5.11\%), but lower than in Primorje-Gorski Kotar County (6-7 age group 9.7\% and 13-14 age group $8.4 \%)$ and Split-Dalmatia County $(9.7 \%)^{12}$. The prevalence of rhinoconjunctivitis was higher in Zagreb (12.13\%), than in this (Brod-Posavina County 9.9\%) and other Croatian studies (Međmurje County 7.14\% and Primorje-Gorski Kotar County - 6-7 age group $5.6 \%$ and $13-14$ age group 6.7\%). Eczema was most prevalent in Brod-Posavina County (10.1\%), compared to another three studies (Zagreb 6.1\%, Međimurje County 5.34\%, and Primorje-Gorski Kotar County -
6-7 age group 6.1\% and 13-14 age group 4.8\%). According to the results of previous Croatian studies, the authors recorded different prevalence of asthma and allergic disease in various regions. That could have been influenced by different geographic location, climate, diet, vegetation and socioeconomic factors. ISAAC reports show wide variability in the prevalence of allergic diseases, not just among regions but also among centers within the same county. Prevalence rates did not correlate with economic status, altitude and air pollution. The great variability observed has also suggested an important role of individual exposures and lifestyle, as well as of genetic background ${ }^{20}$. According to data from different parts of Croatia, moderate prevalence rates of asthma, rhinoconjunctivitis and eczema were observed among Croatian schoolchildren in the period from 2005 to 2011, whereas a recent study revealed a further rising trend ${ }^{10}$.

Atopic sensitization has long been known to be related to childhood asthma ${ }^{21}$. ISAAC Phase II investi- 
gated the prevalence of atopic sensitization and its role in asthma. It included 54,439 children from 22 countries, of which 31,759 underwent SPT. The prevalence of SPT reactivity was lowest in Kintampo, rural Ghana (1.7\%) and highest in Hong Kong, China (45.3\%). There was no correlation of the prevalence of current wheeze and atopic sensitization with gross national income (GNI). However, researchers observed that associations between atopic sensitization and asthma symptoms increased with economic development ${ }^{1}$.The prevalence of atopy was $20.2 \%$. SPT positive for at least one of the allergens used was a strong risk factor for current wheeze and symptoms of rhinoconjunctivitis. Croatia, located in Central Europe, had GNI of 19,731 US\$ per capita. The prevalence of atopy and association with asthma were similar to the prevalence of atopy in countries with similar GNI per capita, such as Estonia, Turkey, and Latvia ${ }^{1}$.

Recent research has shown that the relationship between allergen exposure, atopy and asthma is not clear. Atopy and asthma are not single phenotypes. Allergen exposures in the interaction with other environmental exposures had different outcomes on atopy and asthma phenotypes, depending on individual genetic background ${ }^{22}$.We observed the importance of asthma heredity in our research. Family history of atopy, especially atopic mothers, increased the risk of asthma in their offspring. Asthma was more common among boys than girls, which might be explained by anatomic differences of lungs in preschool period. Environmental exposures such as allergens and specific sensitization may play an important role in particular asthma phenotypes $^{23}$. SPT reactivity to indoor (D. pteronyssinus) and outdoor (grass, ragweed) allergens increased the risk of asthma in our study group. Tobacco smoke is the most prevalent indoor pollutant. It is estimated that half the children worldwide are exposed to second-hand smoke. In utero and childhood exposure to environmental tobacco smoke is associated with an impaired lung function and is a risk factor for development of asthma ${ }^{24}$. In our study population, tobacco smoke exposure by the mother was recorded in 19.3\% of the children in utero and $30.7 \%$ of the children during the $1^{\text {st }}$ year of life. According to different cross sectional studies, the prevalence of mothers that smoke during pregnancy varies among different populations (4.4\%-28.7\% $)^{25}$. In our study, children exposed to environmental tobacco smoke in infancy had twofold greater risk of asthma. Our results are consistent with the observation that environmental tobacco smoke exposure in early life by the mother (mother smoking during pregnancy and $1^{\text {st }}$ year of life) is associated with impaired lung function and constitutes a risk factor for development of asthma ${ }^{24}$.

Modern diet characterized by an increased consumption of meat and fast food has been suggested to be a risk factor for asthma ${ }^{26}$. However, we found no significant association between diet and asthma symptoms (low frequency of fast food consumption in our study population). Rhinoconjunctivitis was strongly associated with family history of allergic disease, whereas sensitization to $D$. pteronyssinus, ragweed and birch increased the risk of nasal symptoms. In addition, we observed a protective effect of rural setting in early life on current rhinoconjunctivitis symptoms. Previous studies have concluded that growing up in rural environment (through contact with farm animals, stables, endotoxin, and consumption of unpasteurized milk, more pets and siblings) reduces the prevalence of atopy, hay fever and asthma ${ }^{27,28}$.

Interaction between susceptibility genes, environment and immune factors contributes to the pathogenesis of eczema. Heredity is complex and includes mutations in a number of genes (genes of skin barrier and genes of innate and adaptive immunity). In this study, family history of atopic disease and female gender increased the risk of eczema. Croatian authors from Medimurje analyzed the risk factors for development of atopic dermatitis in children. Their results, as well as the results from other epidemiologic studies, are consistent with our conclusion ${ }^{14}$. Mutation in skin barrier genes impairs skin integrity and reduces resistance to external influences. Damaged skin facilitates penetration of allergens and contributes to the development of sensitization to aeroallergens. This might explain the higher proportion of SPT positive for $D$. pteronyssinus among children with eczema in our study.

The symptoms of rhinitis and wheezing ever during childhood and during the study period increased the risk of atopic dermatitis in the current study. This is consistent with the majority of epidemiologic studies at the population level, which link allergic disease through 'atopic march' ${ }^{29,30}$. However, research on the heterogeneity of allergic disease at the individual level has shown that concurrence of eczema, rhinitis and asthma is characteristic of only one distinct phenotype ${ }^{31}$. 


\section{Conclusion}

We found a moderate prevalence of allergic disease and atopy among Croatian schoolchildren. The risk factors for allergic disease in our study population included allergic disease in family, atopy, sensitization to indoor and outdoor allergens, and environmental tobacco smoke exposure. The findings from this epidemiologic survey provide a basis for further studies, which would bring better understanding of factors associated with allergic disease in childhood and enable novel public health intervention to reduce the prevalence of asthma.

\section{References}

1. Weinmayr G, Weiland SK, Bjorksten B, et al. Atopic sensitization and the international variation of asthma symptom prevalence in children. Am J Respir Crit Care Med. 2007;176: 565-74.https://doi.org/10.1164/rccm.200607-994OC

2. Rodriguez A, Vaca M, Oviedo G, et al. Urbanisation is associated with prevalence of childhood asthma in diverse, small rural communities in Ecuador. Thorax. 2011;66:1043-50.

http://dx.doi.org/10.1136/thoraxjnl-2011-200225

3. Ronchetti R, Villa MP, Barreto M, et al. Is the increase in childhood asthma coming to an end? Findings from three surveys of schoolchildren in Rome, Italy. Eur Respir J. 2001;17: 881-6.

4. Kalyoncu AF, Selcuk ZT, Enunlu T, et al. Prevalence of asthma and allergic diseases in primary school children in Ankara, Turkey: two cross-sectional studies, five years apart. Pediatr Allergy Immunol. 1999;10:261-5. doi: 10.1034/j.1399-3038.1999.00031

5. Akinbami LJ, Schoendorf KC. Trends in childhood asthma: prevalence, health care utilization, and mortality. Pediatrics. 2002;110:315-22.doi: 10.1542/peds.110.2.315

6. Braun-Fahrlander C, Gassner M, Grize L, et al. No further increase in asthma, hay fever and atopic sensitisation in adolescents living in Switzerland. Eur Respir J. 2004;23:407-13. doi: 10.1183/09031936.04.00074004

7. Beasley R, Ellwood P, Asher I. International patterns of the prevalence of pediatric asthma - the ISAAC program. Pediatr Clin North Am. 2003;50:539-53. https://doi.org/10.1016/S0031-3955(03)00050-6

8. Civelek E, Cakir B, Orhan F, et al. Risk factors for current wheezing and its phenotypes among elementary school children. Pediatr Pulmonol. 2011;46:166-74.

DOI: $10.1002 /$ ppul.21346

9. Aberle N, Reiner-Banovac Ž. Epidemiological examination of asthma in children. Paediatr Croat. 1998;42:9-14.

10. Banac S, Rozmanic V, Manestar K, et al. Rising trends in the prevalence of asthma and allergic diseases among school chil- dren in the north-west coastal part of Croatia. J Asthma. 2013; 50:810-4. https://doi.org/10.3109/02770903.2013.803115

11. Banac S, Tomulić KL, Ahel V, et al. Prevalence of asthma and allergic diseases in Croatian children is increasing: survey study. Croat Med J. 2004;45:721-6.

12. Gudelj I, Mrkic Kobal I, Munivrana Skvorc H, et al. Intraregional differences in asthma prevalence and risk factors for asthma among adolescents in Split-Dalmatia County, Croatia. Med Sci Monit. 2012;18:PH43-50.

DOI: 10.12659/MSM.882609

13. Munivrana H, Vorko-Jovic A, Munivrana S, Kursar M, Medlobi-Gluhak M, Vlahek P. The prevalence of allergic diseases among Croatian school children according to the ISAAC Phase One questionnaire. Med Sci Monit. 2007;13:CR505-9.

14. Munivrana Skvorc H, Plavec D, Munivrana S, Skvorc M, Nogalo B, Turkalj M. Prevalence of and risk factors for the development of atopic dermatitis in schoolchildren aged 12-14 in northwest Croatia. Allergol Immunopathol (Madr). 2014;42: 142-8. DOI: 10.1016/j.aller.2012.10.008

15. Stipić-Marković A, Pevec B, Pevec MR, Čustović A. Prevalence of symptoms of asthma, allergic rhinitis, conjunctivitis and atopic eczema: ISAAC (International Study of Asthma and Allergies in Childhood) in a population of schoolchildren in Zagreb. Acta Med Croatica. 2003;57:281-5. (in Croatian)

16. Stipić-Marković A, Pevec B, Radulović Pevec M, Čustović A, Predović J. Allergic diseases in relationship with environmental factors in a population of school children in Zagreb, Croatia. Arh Hig Rada Toksikol. 2004;55:221-8.

17. Asher I, Keil U, Anderson H, et al. International Study of Asthma and Allergies in Childhood (ISAAC): rationale and methods. Eur Respir J. 1995;8:483-91.

18. Weiland S, Bjorksten B, Brunekreef B, et al. Phase II of the International Study of Asthma and Allergies in Childhood (ISAAC): rationale nad methods. Eur Respir J. 2004; 24: 406-12. DOI: 10.1183/09031936.04.00090303

19. http://isaac.auckland.ac.nz/phases/phasetwo/phasetwomodules.pdf

20. Mallol J, Crane J, von Mutius E, Odhiambo J, Keil U, Stewart A. The International Study of Asthma and Allergies in Childhood (ISAAC) Phase Three: a global synthesis. Allergol Immunopathol (Madr), 2013;41:73-85. DOI: 10.1016/j.aller.2012.03.001

21. Custovic A, Simpson A. Environmental allergen exposure, sensitisation and asthma: from whole populations to individuals at risk. Thorax. 2004;59:825-7.

http://dx.doi.org/10.1136/thx.2004.027334

22. Custovic A. To what extent is allergen exposure a risk factor for the development of allergic disease? Clin Exp Allergy. 2015; 45:54-62. DOI: 10.1111/cea.12450

23. Custovic A, Lazic N, Simpson A. Pediatric asthma and development of atopy. Curr Opin Allergy Clin Immunol. 2013; 13:173-80. DOI: 10.1097/ACI.0b013e32835e82b6

24. Gilliland FD, Li YF, Peters JM. Effects of maternal smoking during pregnancy and environmental tobacco smoke on asthma 
and wheezing in children. Am J Respir Crit Care Med. 2001;163:429-36.

https://doi.org/10.1164/ajrccm.163.2.2006009

25. Pattenden S, Antova T, Neuberger M, et al. Parental smoking and children's respiratory health: independent effects of prenatal and postnatal exposure. Tob Control. 2006;15:294-301. http://dx.doi.org/10.1136/tc.2005.015065

26. Ellwood P, Asher MI, Garcia-Marcos L, et al. Do fast foods cause asthma, rhinoconjunctivitis and eczema? Global findings from the International Study of Asthma and Allergies in Childhood (ISAAC) Phase Three. Thorax. 2013;68:351-60. http://dx.doi.org/10.1136/thoraxjnl-2012-202285

27. Perkin MR, Strachan DP. Which aspects of the farming lifestyle explain the inverse association with childhood allergy? J Allergy Clin Immunol. 2006;117:1374-81. https://doi.org/10.1016/j.jaci.2006.03.008
28. Riedler J, Braun-Fahrlander C, Eder W, et al. Exposure to farming in early life and development of asthma and allergy: a cross-sectional survey. Lancet. 2001;358:1129-33. https://doi.org/10.1016/S0140-6736(01)06252-3

29. van der Hulst AE, Klip H, Brand PL. Risk of developing asthma in young children with atopic eczema: a systematic review. J Allergy Clin Immunol. 2007;120:565-9. https://doi.org/10.1016/j.jaci.2007.05.042

30. Wahn U, Bergmann R, Kulig M, Forster J, Bauer CP. The natural course of sensitisation and atopic disease in infancy and childhood. Pediatr Allergy Immunol. 1997;8:16-20.

31. Belgrave DC, Simpson A, Buchan IE, Custovic A. Atopic dermatitis and respiratory allergy: what is the link. Curr Dermatol Rep. 2015;4:221-7. https://doi.org /10.1007/s13671-015-0121-6

Sažetak

\section{ALERGIJSKE BOLESTI I ATOPIJA MEĐU ŠKOLSKOM DJECOM U ISTOČNOJ HRVATSKOJ}

\section{N. Aberle, B. Kljaić Bukvic, M. Blekic, M. Vučković, D. Bardak, A. Gudelj, G. Čančarević i M. Franić}

Cilj je bio istražiti učestalost alergijskih bolesti i atopije u dječjoj dobi na području Brodsko-posavske županije, moguće etiološke činitelje alergijskih bolesti te usporediti dobivene rezultate s rezultatima istraživača koji su rabili iste metode u Hrvatskoj i u svijetu. Istraživanje je obuhvatilo 1687 školske djece u dobi od 10-11 godina. Primijenjen je standardizirani upitnik Međunarodnog istraživanja o astmi i alergijama u dječjoj dobi za procjenu učestalosti alergijskih bolesti. Ispitanicima za koje smo dobili pismenu suglasnost roditelja učinjen je kožni ubodni test na inhalacijske i nutritivne alergene. Tijekom djetinjstva bronhoopstrukcije je prijavilo $22,7 \%$, simptome rinitisa $22,5 \%$, a simptome atopijskog dermatitisa $17,8 \%$ ispitanika. Učestalost alergijskih bolesti u posljednjih 12 mjeseci iznosila je 7,9\% za bronhoopstrukciju, 9,9\% za simptome rinokonjunktivitisa i 10,1\% za simptome atopijskog dermatitisa. Kožni test učinjen je u skupini od 1070 (63.5\%) djece, od kojih je 20,2\% imalo pozitivan kožni test na najmanje jedan od primijenjenih alergena, s najčešćom senzibilizacijom na alergene grinje. Istraživanjem rizičnih činitelja uočeno je kako alergijske bolesti u obitelji, alergijska senzibilizacija i izloženost duhanskom dimu povećavaju rizik za alergijske bolesti u dječjoj dobi. Usporedbom s drugim međunarodnim centrima Brodskoposavska županija se svrstava u područja s umjerenom učestalošću alergijskih bolesti i atopije u dječjoj dobi.

Ključne riječi: Alergije; Učestalost; Rizični čimbenici; Astma; Rinitis, alergijski; Dermatitis, atopijski; Presječne studije; Dijete; Hrvatska 